\title{
INNOVATION IN UTILITY CRAFTSMANSHIP: ANALYSIS BASED ON HUMAN CAPITAL
}

\author{
José G. Vargas-Hernández ${ }^{1}$ \\ Lic. Jonathan Daniel Chávez Ascencio \\ M.S.C. Omar Cristian Vargas González ${ }^{3}$
}

\begin{abstract}
The objective of this work is to determine the relationship between human capital and artisanal innovation, nowadays, in Tonalá Jalisco, artisanal pieces are produced in an innovative way, either ceramic or any variant of the mud technique, but what A substantial part of the business is what makes innovative business thinking possible. The Intellectus model, created by Eduardo Bueno in 2011, is used as a reference, distinguishing intellectual capital in three types of capital, but for the purpose of this study only analyzed the relationship of human capital with respect to artisanal innovation, the study was conducted in 2018 to 73 craft economic units, it was obtained through the technique of chi square that if there is a positive dependence on human capital and the innovation.
\end{abstract}

Keywords: Competitive advantage, craft, human capital, innovation

JEL Codes: D24, E23, E24, J24, 031.

Citation : Hernandez, J.G.V., et.al. (2020). Innovation in Utility Craftsmanship: Analysis Based on Human Capital, Review of Socio-Economic Perspectives, Vol 5(2), pp. 117-134, DOI : 10.19275/RSEP085.

Article Type: Research Article

Application Date: 18.03.2020 \& Admission Date: 21.05 .2020

DOI: $10.19275 / \mathrm{RSEP} 085$

1. Research professor, Department of Administration, University Center for Economic and Managerial Sciences, University of Guadalajara, Periférico Norte 799 Edif. G201-7 Núcleo Universitario los Belenes Zapopan, Jalisco, 45100, MéxicoＥ-mail: jvargas2006@gmail.com

2. Maestría en Negocios y Estudios Económicos, Centro Universitario de Ciencias EconómicoAdministrativas. Universidad de Guadalajara, Mexico E-mail: djonathan_chavez@hotmail.com

3. Master in Computer Systems, Tecnológico Nacional de México - Instituto Tecnológico de Ciudad Guzmán, Av. Tecnológico 100, Ciudad Guzmán, Jalisco, 49000, México

E-mail: ocvargas@itcg.edu,mx 


\section{Introduction}

The lack of innovative designs, the lack of use of new technology, scarce access to information and communication technologies, adding a lack of knowledge of the market, are problems that artisanal economic units face, preventing the development of products with innovative characteristics that could satisfy the needs of the consumer. There are more problems that have as their origin the absence of business training, highlighting that the artisan businesses are mostly undertaken spontaneously and by tradition, the companies that start the grandparents, are passed from generation to generation (Pérez, 2015). When travel through Tonalá, Jalisco, it can be seen colorful crafts that are distinguished by their beautiful colors, styles and cultural belonging to the region. Unfortunately, there are no unique designs, it could be seen that some artisans sell novel pieces, but if you continue to visit Several establishments can be found with very similar pieces.

\section{Background}

\section{Concepts}

Difference between handcrafts and crafts

The present study takes craftsmanship as an object of research, for this reason it is essential to distinguish between crafts and handicrafts. According to the National Fund for the Promotion of Crafts, crafts is an object or product of community cultural identity, made by manual processes continuous, aided by rudimentary implements and some of mechanical function that lighten certain tasks, and a handcraft is that object or product that is the result of a process of manual or semi-industrial transformation, from a raw material processed or prefabricated (National Fund for the Promotion of Crafts, 2016).

\section{Industry}

Size of craft companies:

In order to classify the companies into micro, small or medium, the criterion of the number of employees is used. In Table 01, the number of employees can be differentiated between the different economic units of the commercial sector. 
Table 1 : Stratification of companies published in the Official Gazette of the Federation (DOF) 30

December 2002

\begin{tabular}{|l|l|l|}
\hline & Sector & Commerce \\
\hline Size & Industry & From 0 a 10 \\
\hline Micro & from 0 a 10 & From 11 a 30 \\
\hline Small & From11 a 50 & From 31 a 100 \\
\hline Median & From 51 a 250 & \\
\hline
\end{tabular}

It is time to classify the artisanal economic units, using the criterion of stratification of the DOF, published on December 30, 2002, it is shown in graphs 01 and 02 that the majority of artisanal enterprises are classified as microenterprises.

Figure 1: Size of ARTISAN ECONOMIC UNITS, Industrial sector

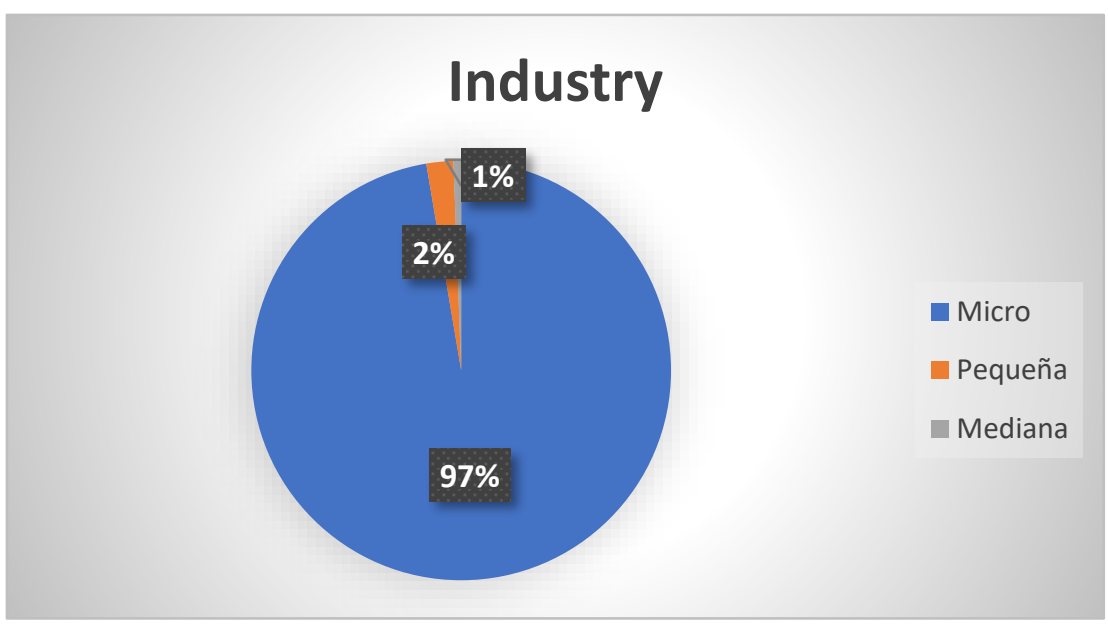

Source: Own elaboration, with data from the National Institute of Statistics and Geography.(2018). 
Figure 2: Size of the ARTISAN ECONOMIC UNITS, Trade sector.

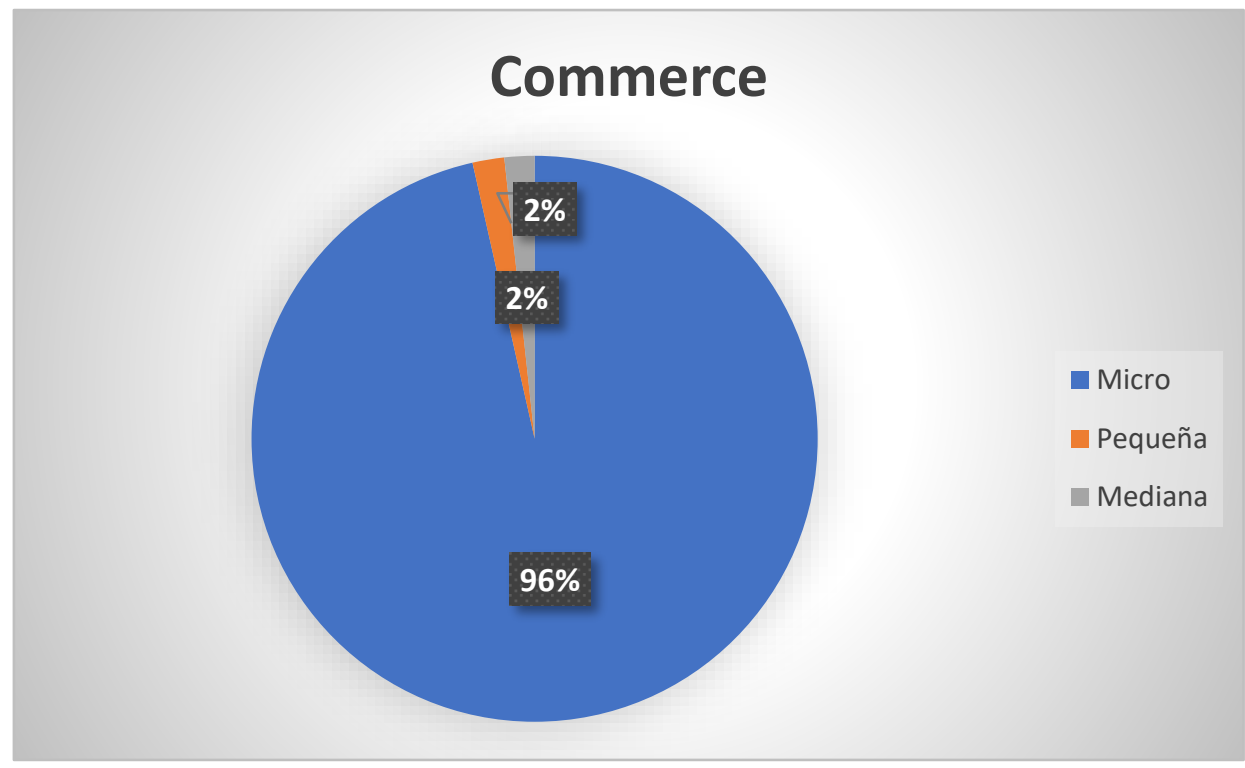

Source: Own elaboration, with data from the National Institute of Statistics and Geography.(2018).

It is found that approximately $97.33 \%$ of industrial ECONOMIC ARTISAN UNITS are classified as microenterprises, while $96.48 \%$ of commercial ARTISAN ECONOMIC UNITS are microenterprises.

\section{Geographical location by sector}

In this section it will be known the concentration of artisanal economic units in the United Mexican States. In figure 01 it can be interpreted that the largest concentration of artisanal economic units is located in Jalisco, Colima and State of Mexico, for this reason the mentioned problem On the low valuation of artisanal products in Tonalá, Jalisco is significant as a significant sample of Mexico. 
Figure 3: Concentration of artisanal economic units in Mexico

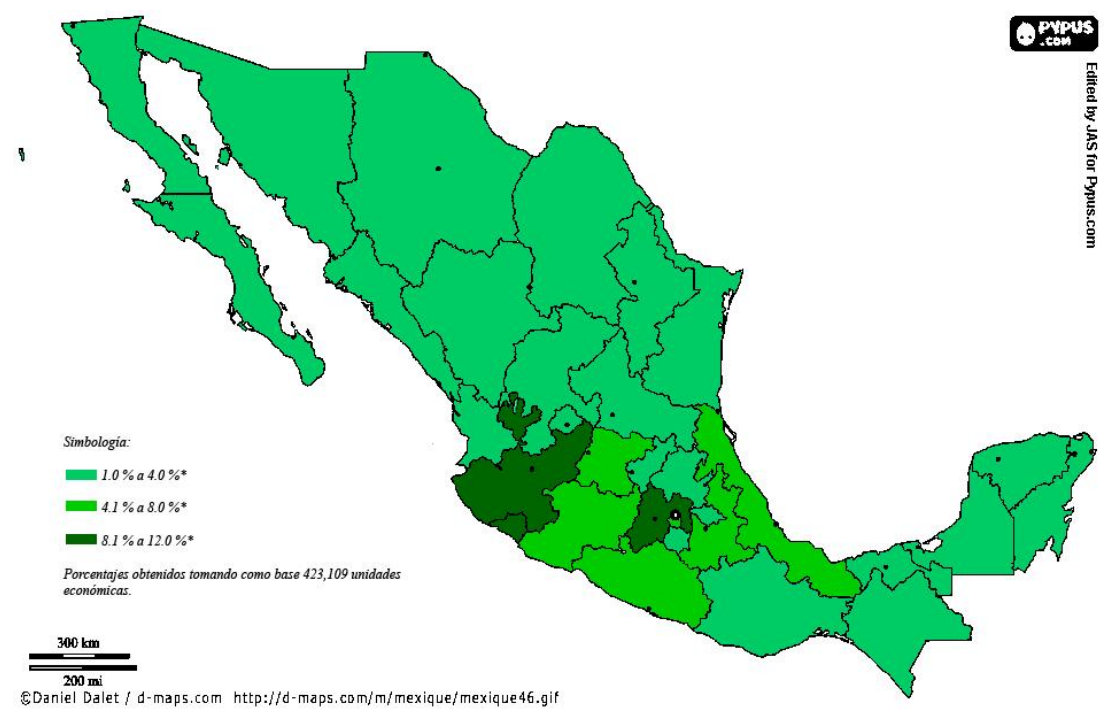

Source: Own elaboration, based on information from the National Institute of Statistics and Geography. (2018).

\section{Craft shops in Tonalá}

People as people have characteristics that distinguish them from others, Tonala reserved nature, craftsmanship qualities for the unique stamp that the authors print in each utilitarian or artistic piece. The potter's talent is an inheritance that has been passed on from generation to generation for hundreds of years, the art in clay is not only manual skill, but expression of the talent with which each potter was born (Ayuntamiento de Tonalá, 2015).

Traditional techniques are still in production today and are listed below:

a) Burnished mud
a) Flagrock
b) Cinnamon mud
c) Clay betus
d) Petatillo clay
e) Black sgraffito
f) Natural mud
g) Polychrome clay 


\section{h) High temperature ceramics \\ i) Contemporary mud}

\section{Competitive advantage}

It is important the valuation of the company that should not be based exclusively on the basis of its financial and economic indicators, since such valuation must fall especially on the intellectual capital of the company (Sánchez, Melián, Hormiga 2007). The correct use of competitive advantages will make the economic unit in question stand out among the existing ones in the same sector.

The intangible resources of the economic units are the main source of sustainable competitive advantage, specifically the intellectual capital that generates value and increases the performance of companies (Bueno, Eduardo Salmador, 2008). Human capital is the intangible non-separable resource par excellence, since it cannot be separated from its carrier, within the separable intangible resources, the following stand out: organizational capital, technological capital and reputation (Fernández Sánchez, Montes Peón, and Vázquez Ordás, 1997).

\section{Theoretical revision}

\section{Human Capital}

Human capital is defined as a generator of value and a source of innovation for the economic unit, from where the ideas of the organization are born (Viedma Martí, 2001). Within human capital three components can be distinguished within this dimension: competences, attitude and intellectual agility, creating in turn new knowledge or discovery that allow improving products or services through ideas (Roos et al., 2001). Assets centered on the individual include collective expertise, creative ability, problem solving skills, and leadership (Brooking, 1997b). It is important to note that not all workers pay creativity or new knowledge to the company, they should be considered exclusively those who are considered experts, that is, they are specialists and represent the elite of the labor payroll (Sveiby, 1998).

The Human Capital for this model evokes knowledge, regardless of its nature that people and groups possess, as well as the process to generate it. Human capital is managed with a strategic purpose paying significantly to the mission and vision of the organization. Knowledge is transmitted from person to person and in society is of vital importance to the organization in order to learn and share information that will benefit the economic unit. Values are actions, human attributes or conditions linked to the well-doing and development of man, in harmony with their environment (Cardona, 2000), the main values highlight commitment, responsibility, tolerance, respect, search for truth and identity, freedom among others, Bueno mentions that values and attitudes are a synergy of each person's being, being and willing. 
The aptitude in the Intellectus model is synonymous with knowledge that people have to achieve a certain performance, highlighting the norms of behavior or organization, specialized knowledge, internally improved knowledge and of course experience is an aptitude that is obtained by the staff of the economic unit.

The capacity is known as the know-how, which refers to the set of skills, skills and talent that the person develops as a result of experience, learning is the ability to respond to the dynamics of change (Bueno, 2011), a capacity that Every human being possesses the communication that, according to Díez Freijeiro, is the capacity that every animated being has to relate to its environment. Human capital refers to the knowledge acquired by a person that increases their productivity and the value of their contribution to the economic unit, includes relationships with other employees, contacts, individual qualities, (Fernández Esteban, 1997).

Intellectual capital

The main objective of knowledge management is to evaluate the competences (knowledge, skills and attitudes) of human capital. It is a strategic tool in the decision making of an organization (Sarur, 2013). On the one hand, intellectual capital is defined as the combination of intangible assets that allow a company to function (Brooking, 1997a). The intellectual capital within a company represents beneficial results to the economic unit transferred to the financial capital, so that the financial accounting is transformed and adopts new concepts, consequently generating a competitive advantage in the market, that is, in correlation with the possession of knowledge, relations with clients, suppliers, experience, organizational technology, professional skills, Etc. (Sarur, 2013).

The company Skandia, in 1991, proposes the Skandia value scheme, considering that the intellectual capital consists of: human capital and structural capital (Sarur, 2013). The Integral Control chart was developed by Kaplan and Norton in the year of 1996, applied in: AT \& T, Eastman, Kodak, American Express and Taco Bell. These organizations have as individuals the operations with which they interact to develop businesses, such as employees, clients and investors, with a view to balanced markers (Sarur, 2013).

On the other hand, the main source of organizations' sustainable competitive advantage resides fundamentally in their intangible assets, reflected in their Intellectual Capital, (Bueno, Salmador, Merino, et al., 2008). Entrepreneurial activity receives particular attention among academics and public policy makers because it is linked, explicitly or implicitly, with economic growth and the general welfare of society (Salas-Fumás \& Sanchez-Asin, 2010). 
Vol. 5 Issue: 2/ June 2020

\section{Intellectus model}

In order to achieve a better understanding of intellectual capital, it is necessary to point out the different synonyms that refer to the capital in question, throughout the work of Lev B. of the year 2001 called Intangibles. Management, measurement and reporting, these synonyms are: intangible assets and knowledge assets.

Intellectual capital is the synergy of all the knowledge that employees possess that give the company a competitive advantage (Stewart, 1998), and the collective of intangible assets can be identified and measured (Malhotra, 2000). Intellectual capital is based on knowledge, experience, skills, information systems, intellectual property, organizational structures, etc. (Robinson and Kleiner, 1996).

The intellectual capital is not only the brain talent of the employees, it also covers the brands, the name of the product, investments that have been made in the past, although they have not been revalued, the market has done so (Edvinsson and Malone, 1999). It is suggested that the intellectual capital of an economic unit be the sum of the knowledge of its members and the practical interpretation of the intangible asset (Roos, Bainbridge and Jacobsen, 2001). The Intellectus model of measurement and management of intellectual capital was published in 2003 by Eduardo Bueno, the structured capital to be measured in contrast to the different measurement models is divided by types of capital.

The Intellectus model of measurement and management of Intellectual Capital was published in 2003 by Bueno E. Its publication was after the international publication of the Skandia model in 1992 by Edvinson. The aforementioned models in synchrony seek identification, definition of numerical indicators, establishment of management and design guidelines on the analysis of intangible assets and non-financial indicators. 
Figure 4 . Intellectus model

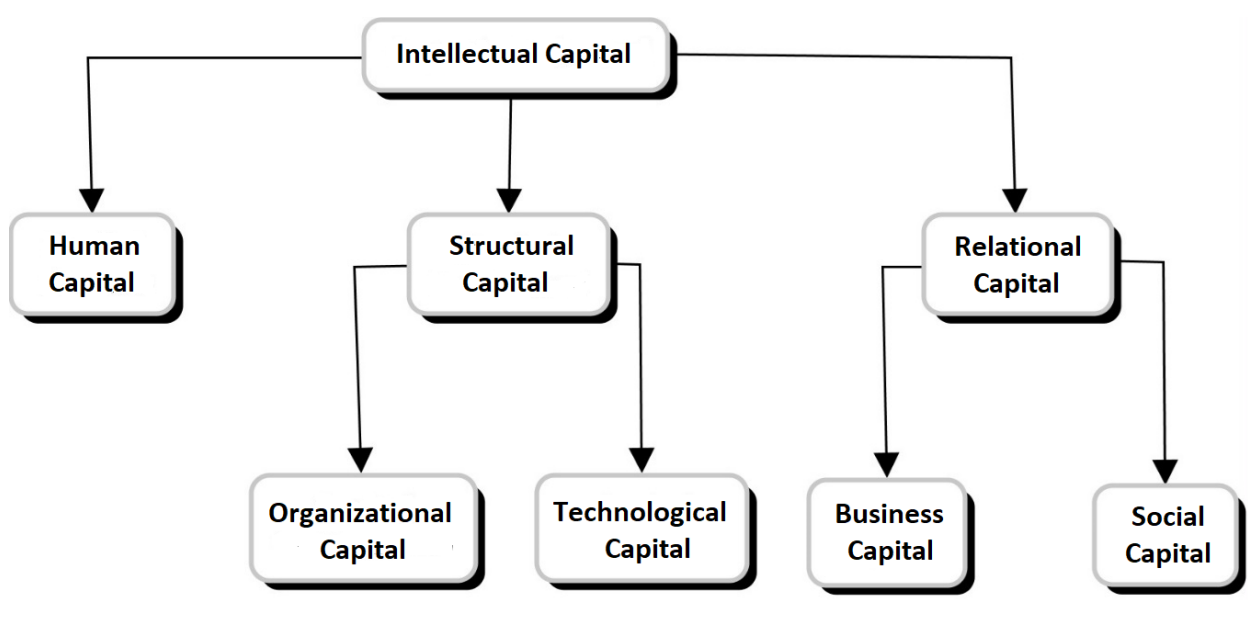

Source: own elaboration based on the Intellectus Measurement Model. management and information of intellectual capital. Madrid: Autonomous University of Madrid.

In 2011 in Madrid Spain the Intellectus model was updated with one of the objectives of improving the logical structure of the model, the new model according to Bueno is systemic, open, flexible, adaptive and dynamic, essentially presents five types of capital: Human Capital, Organizational Capital, Technological Capital, Business Capital and Social Capital, is an open model since the economic unit interacts with its environment and is mainly dynamic, since the present value is directed to the business to reach an estimated future value.

\section{Research methods}

A survey was applied to 73 craft economic units, because the number of artisans is not known, simple random sampling will be used for convenience. The Intellectus model will be taken as a reference for measuring intellectual capital and each element of the capitals that make it up will be operationalized. 
Table 2: Indicators and dimensions of Human Capital.

\begin{tabular}{|c|c|}
\hline Indicators & Dimensions \\
\hline Values and attitudes (to be + be) & $\begin{array}{l}\text { - Feeling of belonging and commitment } \\
\text { - Self-motivation } \\
\text { - Satisfaction } \\
\text { - Sociability and customer orientation } \\
\text { - Flexibility and adaptability } \\
\text { - Creativity }\end{array}$ \\
\hline Skills (know) & $\begin{array}{l}\text { - Regulated education } \\
\text { - Specialized training } \\
\text { - Internal learning } \\
\text { - Experience } \\
\text { - Personal development }\end{array}$ \\
\hline Capacities (know how) & $\begin{array}{l}\text { - Learning } \\
\text { - Collaboration (teamwork) } \\
\text { - Communication (knowledge exchange) } \\
\text { - Reconciling work and family life } \\
\text { - Leadership }\end{array}$ \\
\hline
\end{tabular}

Source: Intellectus measurement model. management and information of intellectual capital. Madrid: Autonomous University of Madrid.

Using the Pearson chi-square technique using the Statistical Package for the Social Sciences (SPSS) program, the qualitative relationship between innovation and human capital was analyzed.

\section{Analysis of results}

The Cronbach's Alpha statistic was performed in order to analyze the reliability of the information, obtaining 0.835 as Cronbach's Alpha index, therefore, it is interpreted that the results obtained have a good reliability. Calculated the value of significance (critical value observed) $0.001<0.05$ rejects the null hypothesis (the variables are independent) and accepts the alternative hypothesis, that is, human capital is significantly related to the capital of entrepreneurship and innovation at a level of $95 \%$ reliability. 
Likewise, a linear regression was performed, to review only the signs of the explanatory variables and we obtained that: Feeling of belonging and commitment, Self-motivation, Satisfaction, Flexibility and adaptability, Personal development, Collaboration (teamwork) and Communication (exchange of knowledge), had a positive sign in their correlation coefficient, therefore qualitatively, it is inferred that the aforementioned aspects of artisanal economic units correlate positively with artisanal innovation.

\section{Conclusions and recommendations}

This research proposes to the artisan businesses a series of variables or aspects to be taken care of in the artisanal business with the aim of improving or expanding entrepreneurship and artisanal innovation. In turn, to be able to create a greater number of artisanal businesses, with a focus of artisanal innovation, which will allow to improve artisanal productivity and be able to continue encouraging the cultural value of artisan pieces, which will give rise to a greater economic and social development of the artisanal field.

Due to the high concentration of artisanal economic units existing in Jalisco, it becomes necessary and interesting to know and analyze the factors and alternatives that artisans have that can allow them to start new businesses and innovate in crafts through administrative strategies that pursue the objectives of each business.

Throughout this research the difference between handicraft and handicrafts was presumed, this difference refers to the object of study of this research, there are several models that measure and determine the intellectual capital in organizations, but the Intellectus model was chosen thanks to its simplicity of understanding and operationalization of variables, the literature revealed that each of the capitals that make up the intellectual capital and in turn help to generate indicators that help the interpretation of results.

Based on the results previously exposed in the chapter on the analysis of results, the conclusions that responded to the objectives and responses of this research can be obtained, as well as the verification of the hypotheses proposed. Recalling that the purpose of this study is to generate contributions that encourage entrepreneurship and innovation in craft economic units.

This research was formulated the general objective of describing the impact that human capital has, that allows to create objectives in the economic unit for the correct management of its resources, through the analysis of a sample of national artisans and Tonaltecas. This with the purpose of to know those factors that allow the artisan businesses to generate entrepreneurship and active innovation within the same businesses, in order to promote a competitive advantage, for the achievement of the general objective it was necessary to know the influence of human capital in the development of craft businesses.

To fulfill the objectives outlined above, it was essential to formulate research questions that would allow identifying and analyzing the critical factors to promote entrepreneurship and artisan innovation, based on the specific objectives the following research question was posed: What is the relationship between human capital and innovation in national craft businesses and Tonaltecas? 
Through the analysis of results, it is concluded that: The human capital of artisan businesses is positively related to craft entrepreneurship.It is recalled that this research project sought to show the characteristics that positively influence entrepreneurship and craft innovation, but due to space and time limitations, each of the characteristics of the different capitals that make up the intellectual capital was not considered more in detail.

\section{References}

Ayuntamiento de Tonalá. (2015). Tonalá tradición viva. Tonalá Jalisco: Amate editorial.

Bueno Eduardo. (2011). Modelo Intellectus de medición. gestión e información del capital intelectual. Madrid: Universidad autónoma de Madrid.

Brooking, A. (1997a). The management of intellectual capital, Long Range Planning, Vol. 30, No. 3, pp. 364-365.

Brooking, A. (1997b), El capital intelectual, Paidós Empresa, Barcelona.

Bueno, Salmador, Merino, et al.. (2008). Génesis, concepto y desarrollo del capital intelectual en la economía del conocimiento: Una reflexión sobre el Modelo Intellectus y sus aplicaciones. Estudios de economía aplicada, 26-2, 43-64. 2018, abril 23

Cardona Sánchez Arturo. (2000). Teoría, reflexiones y respuestas. México, D.F: Grijalbo.

Edvinsson, L. y Malone, M.S. (1999): El capital intelectual, Gestión 2000, Barcelona

Fernández Sánchez, E., Montes Peón, J.M. y Vázquez Ordás, C.J. (1997): La teoría de la ventaja competitiva basada en los recursos: Sintesis y estructura conceptual, Revista Europea de Dirección y Economía de la Empresa, Vol. 6, No. 3, pp. 11-32.

Fondo Nacional para el fomento de las artesanías. (2016). Manual de diferenciación entre artesanía y manualidad. México D.F.: FONART.

Instituto Nacional de Estadística y Geografía. (2018). Directorio Estadístico Nacional de Unidades Económicas . octubre 2018, de INEGI Sitio web: https://www.inegi.org.mx/app/mapa/denue/

Malhotra, Y (2000). Knowledge assets in the global economy: Assessment of national intellectual capital, Journal of Global Information Management, Vol. 8, No. 3, pp. $5-15$.

Pérez Esparza Aimée \& Pelayo Maciel Jorge. (2016). El capital intelectual en la agroempresa familiar cooperativa. Investigación Administrativa, pp46.

Pérez Esparza Aimée. (2015). Redes de negocios y estrategia. El caso de micro y pequeñas empresas artesanales de Tonalá, Jalisco. En Estrategias empresariales, política industrial y competitividad en las pymes (pp. 107-117). México: Pearson. 
Robinson, G. y Kleiner, B. H. (1996). How to measure an organization's intellectual capital, Managerial Auditing Journal, Vol. 11, No. 8, pp. 36-39.

Roos G., Bainbridge A., Jacobsen K. (2001). Intellectual capital as a strategic tool, Strategic \& Leadership, Vol. 29, No. 4, pp. 21-26.

Roos, J., Roos, G., Dragonetti, N.C. y Edvinsson, L. (2001): Capital intelectual. El valor intangible de la empresa, Paidós empresa, Barcelona.

Salas-Fumás \& Sanchez-Asin. 2010. Calidad del recurso emprendedor y productividad en España. En El Trimestre Económico (77, 719-757) España: JSTOR..

Sarur Zanatta M. S. (2013). La importancia del capital intelectual en las Organizaciones. Ciencia Administrativa, No. 1 año 2013: 39-45.

Sánchez Medina, A., \& Melián González, A., \& Hormiga Pérez, E. (2007). El concepto del capital intelectual y sus dimensiones. Investigaciones Europeas de Dirección y Economía de la Empresa, 13 (2), 97-111.

Stewart, T. A. (1998). La nueva riqueza de las organizaciones: el capital intelectual, Granica, Barcelona.

Sveiby, K.E. (1998). Measuring intangibles and intellectual capital - An emerging first standard. Documento obtenido en Internet: http://www.sveiby.com/articles/EmergingStandard.html. (Julio 2002).

Viedma Marti, J.M. (2001). ICBS - Intellectual Capital Benchmarking System, Journal of Intellectual Capital, Vol. 2, No. 2, pp.148-165. 


\section{Appendix}

Reliability statistics

The Cronbach alpha statistic was used, using the SPSS program, using the following formula:

$$
\propto=\frac{K}{K-1}\left[1-\frac{\sum S_{i}^{2}}{S_{t}^{2}}\right]
$$

Where:

$\mathrm{K}: \mathrm{It}$ is the number of items

$S_{i}{ }^{2}$ : Variances of the items

$S_{t}{ }^{2}$ : Variances of the sum of the items

$\propto:$ Cronbach's alpha coefficient

Table 1: Reliability statistics, human capital

Reliability statistics

\begin{tabular}{ll} 
Alfa de Cronbach & N de elements \\
\hline, 835 & 7
\end{tabular}

Case processing summary

\begin{tabular}{llll} 
& & $\mathrm{N}$ & $\%$ \\
\hline Cases & Valid & 73 & 100,0 \\
\cline { 2 - 4 } & Excluded & 0 &, 0 \\
\cline { 2 - 4 } & Total & 73 & 100,0
\end{tabular}

a. The elimination by list is based on all the variables of the procedure.

Source: Own elaboration, with data collected from the instrument 
Vol. 5 Issue: 2/ June 2020

1) Chi-square statistics

The chi-square statistic was used, using the SPSS program, using the following formula:

$$
x^{2}=\sum \frac{\left(o_{i}-e_{i}\right)^{2}}{e_{i}}
$$

Where:

$o_{i}$ : Frequency observed

$e_{i}$ : Expected frequency

$x^{2}$ : Chi - square statistic

Table 2: Summary of case processing chi-square test

\begin{tabular}{|l|l|l|l|l|l|l|}
\hline \multicolumn{2}{|l|l|l|l|}{ Valids } & Tost & \multicolumn{2}{l|}{ Total } \\
\cline { 2 - 8 } & $\mathrm{N}$ & Porcentage & $\mathrm{N}$ & Porcentage & $\mathrm{N}$ & Porcentage \\
\hline $\begin{array}{l}\text { Human capital } \\
\text { Entrepreneurial capital }\end{array}$ & 73 & $100.0 \%$ & 0 & $0.0 \%$ & 73 & $100.0 \%$ \\
\hline
\end{tabular}


Table 3: Table 6 Cross-section table of chi-square test cases

\begin{tabular}{|c|c|c|c|c|c|c|c|c|}
\hline & & & \multicolumn{5}{|c|}{ Capital emprendimiento } & \multirow[b]{2}{*}{ Total } \\
\hline & & & $\begin{array}{c}\text { Totalmente } \\
\text { en } \\
\text { desacuerdo }\end{array}$ & $\begin{array}{c}\text { En } \\
\text { desacuerdo }\end{array}$ & \begin{tabular}{|c|} 
Ni acuerdo ni \\
en \\
desacuerdo
\end{tabular} & De acuerdo & $\begin{array}{l}\text { Totalmente } \\
\text { de acuerdo }\end{array}$ & \\
\hline \multirow{12}{*}{$\begin{array}{l}\text { Capital } \\
\text { humano }\end{array}$} & \multirow{3}{*}{$\begin{array}{l}\text { Totalmente } \\
\text { en } \\
\text { desacuerdo }\end{array}$} & Recuento & 0 & 1 & 0 & 0 & 0 & 1 \\
\hline & & $\begin{array}{l}\text { Recuento } \\
\text { esperado }\end{array}$ & 0 & 0.1 & 0.2 & 0.5 & 0.3 & 1 \\
\hline & & $\%$ del total & $0.00 \%$ & $1.40 \%$ & $0.00 \%$ & $0.00 \%$ & $0.00 \%$ & $1.40 \%$ \\
\hline & \multirow{3}{*}{$\begin{array}{l}\mathrm{Ni} \text { acuerdo ni } \\
\text { en } \\
\text { desacuerdo }\end{array}$} & Recuento & 1 & 0 & 1 & 1 & 0 & 3 \\
\hline & & $\begin{array}{l}\text { Recuento } \\
\text { esperado }\end{array}$ & 0.1 & 0.2 & 0.5 & 1.4 & 0.8 & 3 \\
\hline & & $\%$ del total & $1.40 \%$ & $0.00 \%$ & $1.40 \%$ & $1.40 \%$ & $0.00 \%$ & $4.10 \%$ \\
\hline & \multirow{3}{*}{ De acuerdo } & Recuento & 1 & 1 & 8 & 6 & 3 & 19 \\
\hline & & $\begin{array}{l}\text { Recuento } \\
\text { esperado }\end{array}$ & 0.8 & 1.3 & 3.4 & 8.6 & 4.9 & 19 \\
\hline & & $\%$ del total & $1.40 \%$ & $1.40 \%$ & $11.00 \%$ & $8.20 \%$ & $4.10 \%$ & $26.00 \%$ \\
\hline & \multirow{3}{*}{$\begin{array}{l}\text { Totalmente } \\
\text { de acuerdo }\end{array}$} & Recuento & 1 & 3 & 4 & 26 & 16 & 50 \\
\hline & & $\begin{array}{l}\text { Recuento } \\
\text { esperado }\end{array}$ & 2.1 & 3.4 & 8.9 & 22.6 & 13 & 50 \\
\hline & & $\%$ del total & $1.40 \%$ & $4.10 \%$ & $5.50 \%$ & $35.60 \%$ & $21.90 \%$ & $68.50 \%$ \\
\hline \multirow{3}{*}{ Total } & & Recuento & 3 & 5 & 13 & 33 & 19 & 73 \\
\hline & & $\begin{array}{l}\text { Recuento } \\
\text { esperado }\end{array}$ & 3 & 5 & 13 & 33 & 19 & 73 \\
\hline & & $\%$ del total & $4.10 \%$ & $6.80 \%$ & $17.80 \%$ & $45.20 \%$ & $26.00 \%$ & $100.00 \%$ \\
\hline
\end{tabular}

Table 7: Chi-square test

\begin{tabular}{|l|l|l|l|}
\hline & Valor & $\mathrm{gl}$ & $\begin{array}{l}\text { Significación } \\
\text { asintótica (bilateral) }\end{array}$ \\
\hline Chi-square of Pearson & $33.787^{\mathrm{a}}$ & 12 & .001 \\
Reassinabless & 21.881 & 12 & .039 \\
Linear association by linear & 11.488 & 1 & .001 \\
Valid cases & 73 & & \\
\hline
\end{tabular}

A 16 boxes $(80.0 \%)$ have expected a count less than 5 .

The expected minimum count is .04 .

Calculated the value of significance (critical value observed) $0.001<0.05$ rejects the null hypothesis (the variables are independent) and accepts the alternative hypothesis, that is, human capital is significantly related to the capital of entrepreneurship and innovation at a level of 95 Reliability\%. 
Review of Socio-Economic Perspectives

Hernandez, J.G.V., et.al., pp. 117-134

Vol. 5 Issue: 2/ June 2020

Multiple linear regression

The Stata program, the linear regression command, was used to estimate the sign that would have had a synergy effect on artisanal innovation and the following results were obtained.

Artisanal innovation

$$
\begin{aligned}
& =0.13 \text { hum } 01+0.01 \text { hum } 02+0.05 \text { hum } 03+0.05 \text { hum } 04+0.03 \text { hum } 05 \\
& +0.09 \text { hum } 06+0.019 \text { hum } 019
\end{aligned}
$$

Where:

Hum01: Feeling of belonging and commitment

Hum02: Self-motivation

Hum03: Satisfaction

Hum04: Flexibility and adaptability

Hum05: Personal development

Hum06: Collaboration (teamwork)

Hum07: Communication (knowledge exchange) 
Review of Socio-Economic Perspectives

Hernandez, J.G.V., et.al., pp. 117-134

Vol. 5 Issue: 2/ June 2020

Table 8: Linear regression of human capital with respect to artisanal innovation

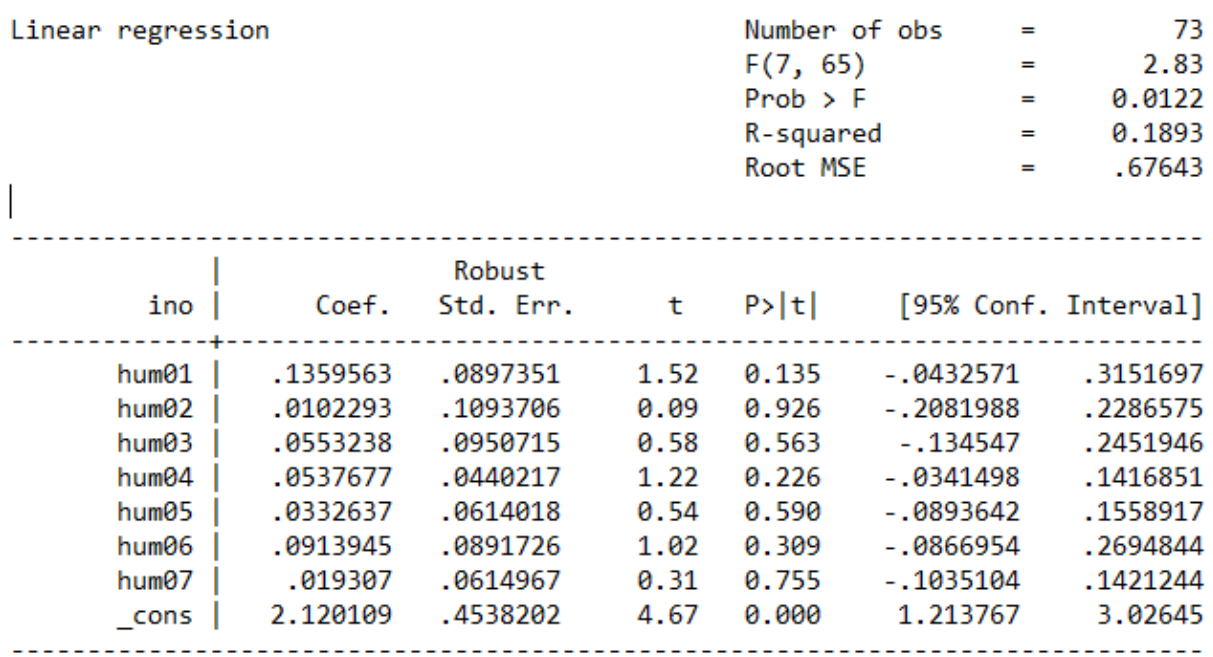


